\title{
Biomass of Eichhornia crassipes, (Mart) Solms. In the Chacororé-Sinhá Mariana, lake System Pantanal of Mato Grosso, Brazil
}

\author{
Biomassa de Eichhornia crassipes, (Mart) Solms. no Sistema de Baías Chacororé-Sinhá Mariana, \\ Pantanal of Mato Grosso, Brasil
}

Biomassa de Eichhornia crassipes, (Mart) Solms. en el sitema de lagos Chacororé-Sinhá Mariana, Pantanal of Mato Grosso, Brasil

\begin{abstract}
The Pantanal constitutes the biggest floodplain of the world, forming a mosaic of different habitats, sustaining rich aquatic and terrestrial biota. This mosaic of habitats of the Pantanal is well represented in the Barão de Melgaço region by the Chacororé-Sinhá Mariana Lake System, this system of parental lakes of Cuiabá river are recognized by their aquatic productivity and scenically beauty. The aquatic macrophyte are very abundant organisms being considered the most productive community in the aquatic system, with great capacity of accumulate biomass and nutrients. The samples were collected into three stations representing the Chacororé-Sinhá Mariana lakes and the transition between them. This study had as purpose to evaluate the spatial and temporal dynamic of biomass in E. crassipes in the stands of this specie in Chacororé-Sinhá Mariana "baía" system. The results shown that both lakes shown bigger biomass during flood, and that in transition sample area were verified the bigger biomass of studied areas. This research supports another studies realized in the Pantanal about the importance of the "flood pulse" in the temporal variation of the biomass and shown that the variation of the biomass of E. crassipes in the lakes evidence the spatial heterogeneity which exists between those lakes. In this way the aquatic macrophyte can indicate the impacts resulting of the hydrological changes in this system of lakes.
\end{abstract}

Keywords: Temporal dynamic; Flood pulse; Aquatic macrophyte; Heterogeneity.

\section{Resumo}

O Pantanal constitui-se na maior planície alagável do mundo, englobando um mosaico de diferentes habitats, sustentando rica biota aquática e terrestre. Este mosaico de habitats do Pantanal é bem representado no município de Barão de Melgaço pelo sistema de baías Chacororé-Sinhá Mariana, este sistema de baías, lagoas parentais do rio Cuiabá são reconhecidas pela sua produtividade aquática e beleza cênica. As macrófitas aquáticas são organismos extremamente abundantes no Pantanal sendo considerada a comunidade mais produtiva dos sistemas alagáveis, com grande capacidade de acumulação de biomassa e nutrientes. As coletas foram realizadas em três pontos de coleta, Baía Chacororé, Baía Sinhá Mariana e a transição entre elas. Este estudo teve como objetivo avaliar a dinâmica espacial e temporal da biomassa de E. crassipes no Sistema de Baías Chacororé-Sinhá Mariana. Os resultados mostraram que as duas baías apresentam maior biomassa durante a cheia, e que no ponto de coleta da área de transição foi verificada a maior biomassa das áreas estudadas. Esta pesquisa corrobora outros estudos realizados no Pantanal sobre a importância do pulso de inundação na variação temporal da biomassa e mostra que a variação da biomassa de E. crassipes nas baías evidência a heterogeneidade espacial existente entre estas. Dessa forma as macrófitas aquáticas podem indicar os impactos resultantes das mudanças hidrológicas nesse sistema de baías.

Palavras-chave: Dinâmica temporal; Pulso de inundação; Macrófitas aquáticas; Heterogeneidade. 


\section{Resumen}

El Pantanal es la llanura de inundación más grande del mundo, abarcando un mosaico de diferentes hábitats, sosteniendo rica biota acuática y terrestre. Este mosaico de hábitats del Pantanal está bien representado en Barão de Melgaço por el sistema de Baías Chacororé-Sinhá Mariana, este sistema de baías de las lagunas parentales del río Cuiabá son reconocidos por su productividad acuática y belleza escénica. Los macrófitos acuáticos son organismos extremadamente abundantes en el Pantanal y son considerados la comunidad más productiva de sistemas inundados, con gran capacidad de biomasa y acumulación de nutrientes. Las colecciones se llevaron a cabo en tres estaciones que representan la Baía de Chacororé, la Baía de Sinhá Mariana y el punto de transición entre ellas. Este estudio tenía como objetivo evaluar la dinámica espacial y temporal de la biomasa de E. crassipes en los stands de esta especie en el sistema de baía Chacororé-Sinhá Mariana. Los resultados mostraron que las dos baías presentan mayor biomasa durante la inundación, y que en el punto de recogida del área de transición se verificó la biomasa más alta de las áreas estudiadas. Esta investigación corrobora con otros estudios realizados en el Pantanal sobre la importancia del pulso de inundación en la variación temporal de la biomasa y muestra que la variación de E. crassipes biomasa en las baías evidencia la heterogeneidad espacial existente entre ellas. Por lo tanto, los macrófitos acuáticos pueden indicar los impactos resultantes de los cambios hidrológicos en este sistema de baía.

Palabras clave: Dinámica temporal; Pulso de inundación; Macrofitos acuáticos; Heterogeneidad.

\section{Introduction}

E. crassipes has been cited like a specie with high values of biomass, 8.6 to 24t. ha ${ }^{-1}$ (Poi de Neiff, 1994), comparison of the biomass of E. crassipes with another species of aquatic macrophytes in the medium Paraná being that this specie shown more than ten times bigger than another species. To Pott and Pott (2000) this specie reaches 200t.ha. year, Da Silva (1990) found 1480g.DW.m² in the Pantanal of Mato Grosso.

Limnological studies realized in the water bodies belonging to river-plain systems of flooding has shown a serial of changes arising from the seasonal variation of the water level, like changes in the water transparency, in the $\mathrm{pH}$, electrical conductivity, in the suspended material, in the nutrient concentration and in the biotic community. (Hamilton \& Lewis Jr, 1990; Da Silva, 1990; Da Silva \& Esteves, 1995; Junk \& Da Silva 1995; Hamilton et al., 1996; Da Silva \& Figueiredo, 1999; Schessi, 1999, Abdo \& Da Silva, 2004, Nunes et al., 2006, Nunes \& Da Silva (2009).

Before from the seasonal changes caused by the water level variation, aquatic environment into the flooding plain shown spacial limnological variation, because of the macrophyte cover, wind, genesis, drainage standard, diversity of terrestrial environment surrounding the area, between another factor already seen by Nogueira (1989); Panoso (1993); Hamilton et al. (1996), Da Silva and Figueiredo (1999), Ramachandra et al. (2002), Nunes et al. (2017), Santos et al. (2017) between another.

This study had as objective to analyses the spacial and temporal variation of biomass of E. crassipes into three sample points in the Chacororé-Sinhá Mariana Baía System.

\section{Methodology}

To the fields samples were selected three points in the Chacororé-Sinhá Mariana "baía" system, being the first one (point 1) in the Chacororé "baía" located in the 21k 0615537 and 8196165 UTM to 158above sea level. The points 2 and 3 are localized in the Sinhá Mariana "baía" being the point 2 situated in the confluence of this one with the Mutum river, is denominated in this point by Sinhá Mariana/Mutum (21k 0615957 and 8195963 UTM and 153m above sea level). The 3 point shows the transition between the water of Sinhá Mariana and Chacororé (21k 0615826, 8192922 to $147 \mathrm{~m}$ above sea level) although situated in the Sinhá Mariana "baía" receive water of Chacororé "baía" though the Do Mato "Corixo". The collects were realized during dry season of 2001 year (July and August) and during the raining season of the 2002 year (February and March), in sample points situated in the littoral region. 
To evaluate the biomass, the samples were collected through the "Harvest" method, with squares with $0.25 \mathrm{~m}^{2}$ which were throw randomly in the stands of E. crassipes in which squares were collected all parts of the plants (blade, petiole, rhizome, root, stolon and detritus) till the hands reach (flood season) or till the soil (dry season). In the laboratory was cleaned with current water. Those were packaged into paper bags and carried to heater (Heraeus instruments) under $60^{\circ} \mathrm{C}$ degrees and dehydrated till constant weight, when their structures were weighted into analytical scale (Sartorius laboratory), with two houses of precision. After weighted, it was processed the calculation to obtain values of biomass.

The Physical-Chemical variables of water were measured in field, under macrophyte cover, are described in Nunes and Da Silva (2005), Nunes et al. (2020) and Abdo et al (2012).

The data of pluvial precipitation, sunstroke, relative air humidity and evapotranspiration to the period of September of 2000 to August of 2002, were obtained in the Agroclimatic Station Padre Ricardo Remetter from Mato Grosso Federal University located in the Santo Antonio do Leverger town (Lat. 15 51'S; Long. 56 $04^{\circ}$ 'W; to 140m.a.s.1.) and are described in Nunes and Da Silva (2005).

To statistical analysis of the data were used the program SPSS (Statistical Package for Social Science) ANOVA, Levene, Wilcoxon-Nemenyi-McDonald-Thompson texts. To calculate the biomass supplies total were used the values already calculated to biomass $\left(\mathrm{gDWm}^{2}\right)$ and multiplicated by the length and width of each stand of E. crassipes, these values were measured during sample collects.

\subsection{Study área}

The research was developed in the Chacororé-Sinhá Mariana Baía System, in the Santo Antônio de Leverger and Barão de Melgaço municipality, situated between the coordinates $16^{\circ} 14^{\prime}$ to $16^{\circ} 16^{\prime}$ Sulth latitude and $55^{\circ} 55^{\prime}$ a $55^{\circ} 58^{\prime}$ of West longitude, in downstream of the Barão de Melgaço county (Figure 1). This system of "baías" (Chacororé-Sinhá Marina), connects to Cuiabá river, by means of a net of "corixos" Da Silva et al (2012) e Nunes et al (2012).

According to Pinto-Silva (1980) e Nunes et al (2012) the Chacororé lake show turbid water, is a lake with a semicircular shape, situated to $125.20 \mathrm{~m}$ above sea level and with the following morphometric characteristics: maximum width, $10.18 \mathrm{Km}$, maximum wide, $9.88 \mathrm{Km}$, medium wide, $6.00 \mathrm{Km}$, maximum depth, $4.00 \mathrm{~m}$, medium depth, $2.75 \mathrm{~m}$, volume, $178.6 \mathrm{x}$ $10^{6} \mathrm{~m}^{3}$, area, $64.92 \mathrm{Km}^{2}$. 
Figure 1. Study area localization in the Chacororé-Sinhá Mariana lake system, Pantanal Mato-grossense, Barão de Melgaço, MT, Brazil.

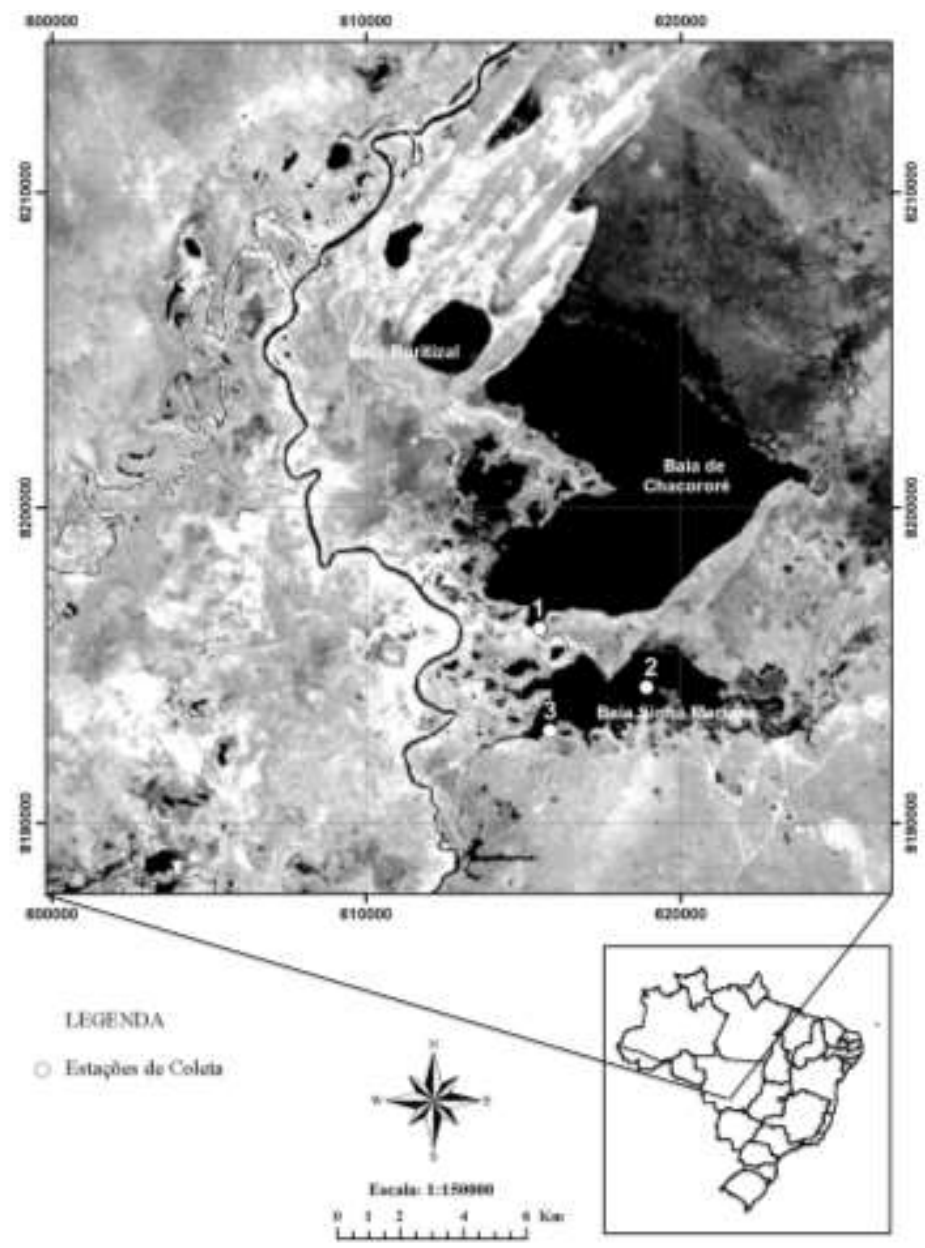

Source: Authors.

The Sinhá Mariana "baía” had black water, is formed by an enlargement of the Mutum river with one became linked during all year, and apart from which drain in the Cuiabá River. Was described by Pinto-Silva (1980), like a lake with elongate shape, with the following morphometries characteristics: maximum width, $8.75 \mathrm{Km}$, maximum wide, $2.67 \mathrm{Km}$, medium wide, $1.29 \mathrm{Km}$, maximum depth, $4.75 \mathrm{~m}$, medium depth, $3.58 \mathrm{~m}$, volume, $40.40 \times 10^{6} \mathrm{~m}^{3}$, area $11.25 \mathrm{Km}^{2}$.

\section{Results}

The biggest biomass values of E. crassipes were obtained during flood season, following the hydrological cycle, being 7261.44gDW.m ${ }^{-2}$ in Chacororé in February, 7034.08gDW.m ${ }^{-2}$, for Sinhá Mariana/Mutum in March and 7534.56gDW.m² for Sinhá Mariana/Chacororé in February (Figure 2) being that the last shown bigger biomass in all studied area. 
Figure 2. Variation of biomass (g. DW. $\mathrm{m}^{2}$ ) of the aerial structures of E. crassipes and the water surface of the ChacororéSinhá Mariana "Baía" system.
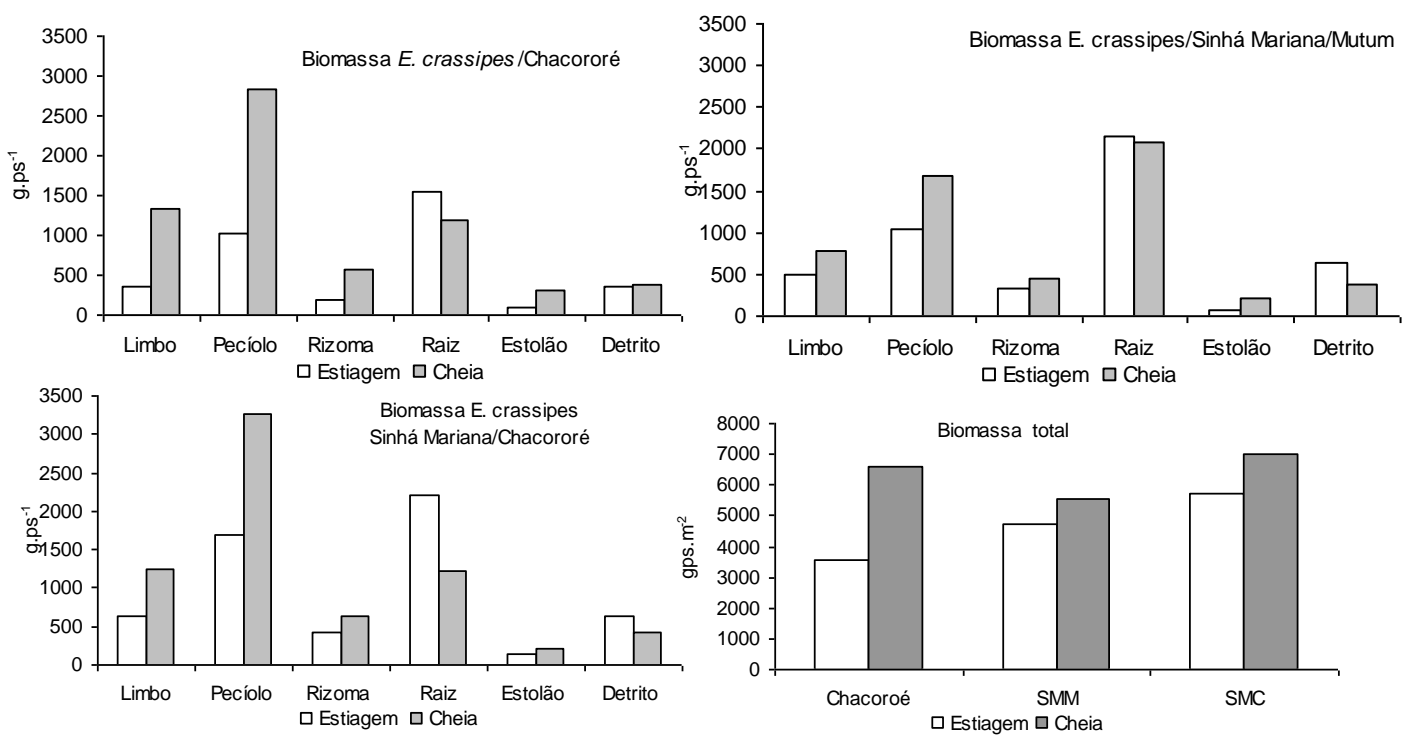

Source: Authors.

In the dry season the total biomass accumulated for all samples points was of $2710.21 \mathrm{gDW} . \mathrm{m}^{-2}$ in August in the Chacororé "baía", 2449.76gDW.m ${ }^{-2}$ in August in Sinhá Mariana/Mutum and 5133.39gDW.m² in August in the Sinhá Mariana/Chacororé "baía”. Sinhá Mariana/Mutum show the small total biomass.

In Chacorore there was an increase of the biomass of blade and petiole in the high water period, the root shown the bigger biomass in the dry period probably because during this phase the plant is near of the sediment. The rhizome, stolon and detritus almost not showed variation in the biomass between hydrological periods. The structures of E. crassipes which most contributes to the increase of the biomass during high water period were: petiole with $2835.44 \mathrm{gDW} . \mathrm{m}^{-2}(38.15 \%)$, the blade with $1334.99 \mathrm{gDW} . \mathrm{m}^{-2}(22.60 \%)$ and the root with $1199.97 \mathrm{gDW} . \mathrm{m}^{-2}$ that although not showed bigger biomass during flood, showed anyway high biomass values (21.94\%) (Figure 3).

In Sinhá Mariana/Mutum, had also an increase of biomass during flood period for petiole $\left(1670.71 \mathrm{gDW} . \mathrm{m}^{-2}\right)$, blade $\left(786.27 \mathrm{gDW} . \mathrm{m}^{-2}\right)$. The root and detritus has obtained bigger biomass during dry period respectively, $2149.07 \mathrm{gDW} . \mathrm{m}^{-2}$ and $640.72 \mathrm{gDW} . \mathrm{m}^{-2}$ due the high rate of decomposition on this period and to the fact of E. crassipes be fixed on the sediment from where passed to obtain nutrients. Rizome and stolon not showed variation for the hydrological period. The structure which were responsible by the increase of the biomass were: root with $2075.12 \mathrm{gDW} . \mathrm{m}^{-2}(37.23 \%)$, petiole with $1670.61 \mathrm{gDW} . \mathrm{m}^{-2}$ $(31.70 \%)$ and blade with $786.27 \mathrm{gDW} . \mathrm{m}^{-2}(13.75 \%)$ (Figure 6).

In Sinhá Mariana/Chacororé there was an increase of biomass during flood period for blade and petiole. The root had the inverse way being that the bigger biomass was obtained during dry period, rhizome, stolon and detritus not shown variation. The increase of the biomass during flood period were: petiole with $3254,21 \mathrm{gDW} . \mathrm{m}^{-2}$ (44.91\%), blade with 1239.60gDW.m ${ }^{-2}(18.08 \%)$ and root with 1223.52gDW.m ${ }^{-2}(17.44 \%)$. On all samples points the petiole, blade and root shown increase in the biomass in the flood varying only on intensity (Figure 6). 
The blade when analyzed statistically shown significant difference only to hydrological period $\left(\mathrm{N}=36, \mathrm{p}<0.01, \mathrm{r}^{2}\right.$ 0.89). The petiole not showed significant statistical difference spatial, less temporal in the studied area. The rhizome showed statistical difference only when compared temporally $\left(\mathrm{N}=36, \mathrm{p}<0.01, \mathrm{r}^{2} 0.91\right)$. The root not showed significant statistical difference for time less for space. Stolon and detritus not showed significant statistical difference for time or space. The Levene test showed that there is significant difference for total biomass in relation to hydrological cycle $(\mathrm{N}=36, \mathrm{P}<0.05$, $\mathrm{r}^{2}=0.35$ ) not showing significant difference between sample points.

The total biomass accumulated during dry and flood period for Sinhá Mariana/Chacororé was of $5718.88 \mathrm{gDWPS} . \mathrm{m}^{-2}$ and $7003.76 \mathrm{gDW} . \mathrm{m}^{-2}$ respectively being this sample point that shown bigger also for dry and flood season. In Chacororé was measured $3574.55 \mathrm{gDW} . \mathrm{m}^{-2}$ and $6625.68 \mathrm{gDW} . \mathrm{m}^{-2}$ for dry and flood period, being the second bigger biomass of the flood and the small of the dry. This just occurs because Sinhá Mariana/Mutum showed biomass very high of root $\left(2149.07 \mathrm{gDW} . \mathrm{m}^{-2}\right)$ and for this stay more elevated in dry period than Chacorore that show only $\left(1547.17 \mathrm{gDW} . \mathrm{m}^{-2}\right)$ (Figure 3).

Figure 3. Biomass variation (g.DW. $\left.\mathrm{m}^{2}\right)$ on the samples points: Chacororé, Sinhá Mariana Mutum and Sinhá Mariana/Chacororé and total biomass (d) of structures of E. crassipes in the Chacororé-Sinhá Mariana lake system, during dry of 2001 and flood of 2002.

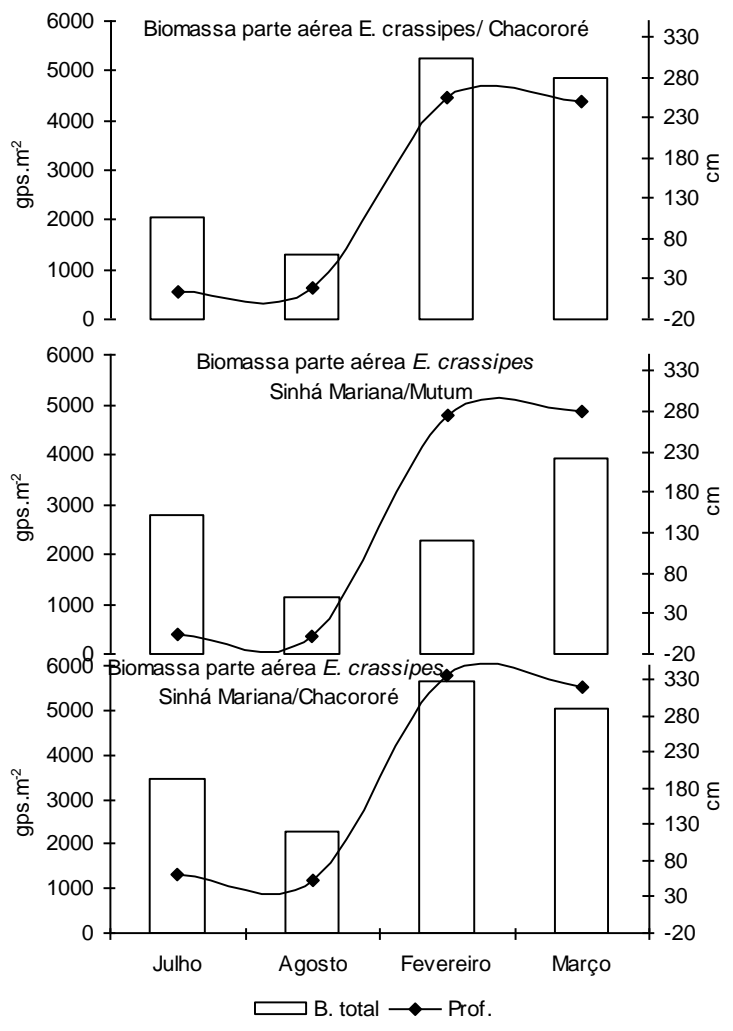

Source: Authors.

The medium accumulated biomass in the collects months calculated for the three samples points were in Sinhá Mariana/Chacorore of 57.19 t.DW.ha ${ }^{-1}$ in the dry period and 70.14 t.DW.ha ${ }^{-1}$ in the flood period this sample point showed the biggest values of biomass as much in the dry as much in the flood period, Chacorore showed the small results in the dry during flood overcome Sinhá Mariana/Mutum and stay like intermediate with values of 33.74 t.DW.ha ${ }^{-1}$ during the dry and 66.26 
t.DW.ha ${ }^{-1}$ during flood, Sinhá Mariana/Mutum had 47.42 t.DW.ha ${ }^{-1}$ during dry and 55.71t.DW.ha ${ }^{-1}$ in flood, those values put Sinhá Mariana/Chacororé like bigger biomass by hectare.

If considered the stock of biomass Chacororé possess a very bigger biomass, because all the stands of E. crassipes had a very bigger area on this lake, (Table I) mainly during flood. The biomass stock in Chacororé was for dry of $107.24 \mathrm{KgDW}$ for the stand where it was realized the collects (Table I) during flood the stock was of $1987.70 \mathrm{KgDW}$ on a stand very bigger in this period. The sample point Sinhá Mariana/Mutum shown stock of biomass of $165.96 \mathrm{kgDW}$ during dry period and $194.63 \mathrm{kgDW}$ during flood period. On the sample point Sinhá Mariana/Chacororé the stock observed was of $457.51 \mathrm{kgDW}$ during dry and $840.45 \mathrm{kgDW}$ during flood period.

Table 1. Size of stands of Eichhornia crassipes in the Chacororé-Sinhá Mariana lake system, during dry of 2001 and flood of 2002.

\begin{tabular}{ccc}
\hline Sample points & \multicolumn{2}{c}{ Collected stand $(\mathrm{m})$} \\
\hline Chacororé & Dry & Flood \\
Sinhá Mariana/Mutum & $60 \times 0.5$ & $300 \times 1$ \\
Sinhá Mariana/Chacororé & $70 \times 0.5$ & $70 \times 0.5$ \\
\hline
\end{tabular}

Source: Authors.

During dry of 2001, almost was not observed individuals of E. crassipes on Chacororé, while many individuals of $E$. azurea were easily observed, during flood of 2002 just were observed large stands of E crassipes on the sample point and E. azurea was not observed, showing a substitution between these species during water level variation related to flood pulse. On Sinhá Mariana/Mutum E. azurea was the most common specie, although it was not difficult to found E. crassipes together with the mixed stands of those species, it was not variation between dry and flood period. On the sample point Sinhá Mariana/Chacororé the stands were mixed between E. azurea and E. crassipes during all sample collect period, although E. crassipes dominate on flood period.

\section{Discussion}

There was hydric deficiency during flood of the 2001 year not being this considered elevated for this region, because Soriano (1996) found values above of $300 \mathrm{~mm}$ in the Pantanal of Nhecolândia. During the collects on dry the evapotranspiration was of $92.6 \mathrm{~mm}$ on July/2001 and 123.8mm on August/2001, overcoming and much the precipitation for the same period, clearing the dryness observed on field. The evapotranspiration overcoming the precipitation on flood of 2001 the same not occurred on 2002 when the water level grows considerable on the sample points in the Chacoroé-Sinhá Mariana lake system growing the area for E. crassipes growing which developed considerable their biomass Nunes and Da Silva (2005).

Tarifa (1986) observed in The Pantanal humidity not less than 62\% in dry till the $84 \%$ during flood those values are very near of the observed on this study, for the same period. The relative air humidity not follow diminish of the temperature which happens after April, this probable due evapotranspiration on those areas. 
According Alfonsi and Camargo (1984) the northern region of Pantanal is more warm than south region, the most could month with temperature over $21^{\circ} \mathrm{C}$ and the warmest over $27^{\circ} \mathrm{C}$, second Thornhwaite, classification The Pantanal is situated on a megatermic region, the values of evapotranspiration overcome $1.140 \mathrm{~mm}$.

On environments when the Flood Pulse is predictable and with long duration, the organisms adapted bringing benefits for their population. Many species reproduce during this period being their seeds overspread by water and fishes (Da Silva 1990; Da Silva \& Esteves 1993, Nunes da Cunha \& Junk 1996) those adaptations move in direction of efficient use of the resources on the ATTZ-aquatic/terrestrial transition zone, where alternate chronologically aquatic and terrestrial environment, establishing differences into the river-plain system including habitats permanent wetted, permanent lotic (main channel), permanent lentic and wetland (ATTZ).

Da Silva and Esteves (1993) observed that the main structures of plants which contributes for the increase the biomass were blade, petiole, root and detritus for E. crassipes blade, petiole and rhizome for E. azurea and for Ludwigia natans, blade, rhizome and detritus. In Chacororé of the six structures verified only petiole, root and blade collaborate significantly for increase of the biomass, on this way it was verified that this specie in The Pantanal has their development linked to the expansion of the mentioned areas.

Conserva (1998) observed monthly biomass of Paspalum fascilulatum in the Solimões River, Central lake of Marchantaria, Island of $1866.96 \mathrm{gDW} . \mathrm{m}^{-2}$ and $1343.78 \mathrm{gDW} \cdot \mathrm{m}^{-2}$ and $2.174 .75 \mathrm{gDW} \cdot \mathrm{m}^{-2}$ to $1722.80 \mathrm{gDW} \cdot \mathrm{m}^{-2}$ during September of 1995 to August of 1996 respectively. Those values are very small than the observed on this study for the monthly medium of $E$. crassipes.

Sinhá Mariana/Mutum behave like Chacororé and like observed by Da Silva and Esteves (1993) although not in the same sequence root, petiole and blade were responsible by the increase of the biomass.

On all sample points petiole, blade and root shown increase on the biomass during flood being that only the order of increase of each one vary the same was observed by Da Silva and Esteves (1993) for the same specie on two lakes of the.

The increase of the biomass on flood for this specie is related to the increase of the free area for the development of this plant which grow as much by clonal reproduction as much sexual reproduction, increasing the occupied area through horizontal grow, expanding also biomass by unit of area through the development of petioles and blades bigger that is to say vertical grow, follow Da Silva and Esteves (1993) the growing of the cited structures of E. crassipes show the vertical grow of the plant, than it is possible to take a base to say that the bigger rate of vertical growing on the studied area occurs on flood, the grow of rhizome and stolon although in small proportion also indicates the horizontal grow observed on field during flood.

Sinhá Mariana/Chacororé showed the biggest biomass due to be situated on a point of confluence of Chacororé and Sinhá Mariana lakes, from where the water during dry drains to Cuiabá River (during rising water and flood the flux direction of water is inverse) this fact permits that this point receive nutrient as much from Chacororé as much from Sinhá Mariana.

The increase of biomass during flood is related also with the keep of the specie in the system, which reduces their biomass during dry, this behavior was observed by Silva (2002), for the E. crassipes specie. Before that the concentration of nutrients on the studied environment was bigger during the flood like cleared by Nunes and Da Silva (2005).

On the Chacororé-Sinhá Mariana lake system the biggest part of the aquatic macrophyte biomass are exported for the Cuiabá river by the "corixos" that connect this system of lakes to the river, this is easily verified during receding phase when big floating blocks (islands) of different size follow to river direction, carrying part of the biomass accumulated during flood, insects, fishes and birds, this fact also was observed by Da Silva and Esteves (1993), on the Porto de Fora lake in The Pantanal.

The increase of root biomass is due that on Sinhá Mariana the amount of ions dissolved in the water is small than in Chacororé the increase of the root area favor the caption of nutrient, the total biomass accumulated in dry on Sinhá 
Mariana/Mutum was $1185.43 \mathrm{gDW} . \mathrm{m}^{-2}$ and during flood was $1392.74 \mathrm{gDW} . \mathrm{m}^{-2}$ being on this way the small biomass accumulated during flood due the stands of E. crassipes being very small on this sample point.

Another fact which contribute for the high concentration of E. crassipes was the grow of ions present in the water during flood mainly in Chacororé and Sinhá Mariana/Chacororé also of geological origins, mainly on Chacororé, as much the decomposition of the terrestrial species now submerged, before still the organic matter carrying of the drainage area for the lake system, add to this fact the high temperature, oxygen concentration and humidity, because it were submerged what helps in a decisive way for decomposition and nutrient liberation (Penha et al., 1998; Villar et al., 2001; Asaeda et al., 2001),carried from riverine wood surrounding the lake system must to contributing to the increase of ion concentration and energy into the system (Guo \& Sims 1999).

Studying an oxbow lake Camargo \& Esteves (1996), observed that the main factors which control the increase of biomass and nutrient concentration in E. azurea were the flood pulse and the increase of ion into the water.

According Da Silva and Esteves (1993) the growing of E. crassipes during flood can be related to the elevated temperature and small thermal amplitude observed in months which precede the flood, Singh and Sahai (1979) also impute the biomass increase of E. crassipes to the rainy days and to the India, Sabatini (1985), also observed the increase of biomass of Paspalum repens during the Flood period on the wetlands of Paraná River.

On chacororé it was calculated a increase of $50.93 \%$ of biomass during dry to flood, on Sinhá Mariana/Mutum the increase was of $14.88 \%$ for the same period, with on Sinhá Mariana/Chacorore the increase was of $18.46 \%$ Da Silva and Esteves (1993) also observed the biggest values of biomass during the flood on the Acurizal and Porto de Fora lakes, both near of the study area of this research for those lakes were obtained increase of $50 \%$ for E. crassipes and decrease of biomass of $59 \%$ for E. azurea and $86 \%$ for Ludwigia natans on the same study area.

Junk and Piedade (1997) and Piedade \& Junk (2000) observed on the Amazonian "várzeas" biomass of Echinochloa polystachya a semi aquatic grass which occupies large areas during dry of about 100tha ${ }^{-1}$, Cyperus papyrus reaches values of about 143 t. PS.ha ${ }^{-1}$ by year, E. crassipes can reach these values, but their natural enemies and the climatological conditions inhibited their productivity.

Pozer and Nogueira (2004) verify a significant difference on biomass of native species of grasses in the Matogrossense Pantanal.

On this way it was verified that the flood pulse develops a very important influence on the increase of biomass of $E$. crassipes on the Chacororé-Sinhá Mariana lake system, allied still to the high temperature observed on field and the nutrient on water. Another important factor is that the system of lakes export nutrients for another regions of the Pantanal thorough the "corixos" which links the lake system to the rivers of the region.

Chacororé was the sample point which show biggest stock of biomass of the studied areas, Sinhá Mariana/Mutum show the small stock of biomass for the specie and Sinhá Mariana/Chacororé showed intermediary values.

\section{Conclusion}

It was possible to sad that Chacororé pass of less productive during dry to be by far the most productive during flood. This factor certainty is linked with the bigger concentration of dissolved nutrients into the water of this lake.

Occurs still the death and reduction of the area of these plants with the arrive of receding phase and consequently diminish of the water volume in the lake system, the export of biomass is a factor to be considered.

In synthesis it was verified in this research that the flood pulse carries a direct and indirect influence on the physical and chemical variables and that these go up with the increase of the water column or diminish arising of the same. 
In general, the Chacororé Lake showed the biggest values of biomass, Sinhá Mariana/Chacororé (transition zone) showed intermediary values and Sinhá Mariana/Mutum the small values.

\section{Acknowledgments}

To The Pantanal Ecology Project (IB-UFMT/MPIL, Plön) supported by SHIFT (CNPq-IBAMA-DLR0 Program, Technical Scientific bilateral cooperation Brasil-Alemanha by the logistic support on this research. To CNPq for concession of master scholarship for first author. To FAPEMAT, by the logistic support for realize of this research and still to the Post Graduate Program in Ecology and Conservation of Biodiversity from Federal University of Mato Grosso.

\section{References}

Abdo, M. S. A. \& Da Silva, C. J. (2004) Limnological characteristics of water bodies of the Corutuba Nesting Site in Brazil's Pantanal, Acta Limnological Brasiliensia. 4(16), 359-368.

Abdo, M.; Da Silva, C. J. \& Nunes, J. R. S.; (2012) Diversidade de Macrófitas Aquáticas do sistema de baías Chacororé-Sinhá Mariana. IN: Água, Biodiversidade e Cultura do Pantanal, Estudos ecológicos e etnoecológicos no sistema de baías Chacororé-Sinhá Mariana, Org. Da Silva, C. J. \& Simoni, J. 272 .

Alfonsi, R. R. \& Camargo M. B. P. (1986) Condições climáticas para a região do Pantanal Mato-grossense, In: Simpósio sobre Recursos Naturais e Socioeconômicos do Pantanal. Corumbá, MS. 29-42.

Allen, S. E. (1989) Chemical Analysis of Ecological Materials. Second Edition. Blackwell Scientific Publications, London, 368p.

Asaeda, T., Trung V. K., \& Manatunge J. (2001) Modeling the effect of macrophyte growth and decomposition on the nutrient budget in shallow lakes, Aquatic botany, 68, 217-237.

Camargo, A. F. M. \& Esteves, F. A. (1996) Influence of water level variation on biomass and chemical composition of the aquatic macrophyte Eichhornia azurea (Kunth) in as oxbow lake of the rio Mogi-guaçu (São Paulo, Brazil), Archieve hydrobiology, 135, 3, 423-432.

Conserva, A. S. (1998) Biomassa, ciclo de vida e composição química de duas populações de Paspalum fasciculatum Willd. Ex, Fluegge (Poaceae) em diferentes habitats de Várzea da Amazônia Central, Dissertação de mestrado. Universidade do Amazonas, Instituto Nacional de Pesquisas da Amazônia, Manaus, Brazil, 90f.

Da Silva, C. J. (1990) Influência da variação do nível d'água sobre a estrutura e funcionamento de uma área alagável do Pantanal Matogrossense (Pantanal de Barão de Melgaço) - MT. São Carlos, SP. (Tese) UFScar, Universidade Federal de São Carlos. $250 f$.

Da Silva, C. J. \& Esteves, F. A. (1993) Biomass of three macrophytes in the Pantanal of the Mato grosso, Brazil Int. J. Ecol. Environ. Sci. 19: 11-23.

Da Silva, C. J. \& Esteves, F. A. (1995) Dinâmica das características limnológicas as baías Porto de Fora e Acurizal (Pantanal de Mato Grosso) em função da variação do nível da água. Oecologia Brasiliensis (I) Estrutura, Funcionamento e Manejo de Ecossistemas Brasileiros. In: Esteves, F.A. (ed). 47-60.

Da Silva, C. J. \& Figueiredo, D. M. (1999) Variação limnológica das baías de Chacororé e de Sinhá Mariana, Pantanal Mato-grossense, Mato Grosso (MT), Revista Mato-Grossense de Geografia, 03/04(03/04), 57-75.

Da Silva, C. J.; Nunes, J. R. S.; Simoni, J.; (2012) O sistema de baías Chacororé-Sinhá Mariana. IN: Água, Biodiversidade e Cultura do Pantanal, Estudos ecológicos e etnoecológicos no sistema de baías Chacororé-Sinhá Mariana, Org. Da Silva, C. J. \& Simoni, J. 272 p.

Da Silva, C. J., Sousa, K. N. S., Ikeda-Castrillon, S. K., Lopes, C. R. A. S., Nunes, J. R. S., Carniello, M. C., Mariotti, P. R., Lazaro, W. L., Morini, A., Zago, B. W., Façanha, C. L., Albernaz-Silveira, R., Loureiro, E., Viana, I.G., Oliveira, R. F., Cruz, W. J. A., Arruda, J.C., Sander, N. L., Freitas Junior, D. S., Pinto, V. R., Lima, A. C. \& Jongman, R. H. G. (2015) Biodiversity and its drivers and pressures of change in the wetlands of the Upper Paraguay-Guaporé Ecotone, Mato Grosso (Brazil). Land Use Policy 47: 163-178. https://doi.org/10.1016/j.landusepol.2015.04.004

Guo, L. B. \& Sims R. E. H. (1999) Litter decomposition and nutrients release via litter decomposition in New Zealand eucalypt short rotation forests, Agriculture esosystems \& environment, 75, 133-140.

Hamilton, S. K. \& Lewis Jr, W. M. (1990) Basin morphology in relation to chemical and ecological characteristics of lakes on the Orinoco River Floodplain, Venezuela. Archieve Hydrobiologia 119 (4): 393-425.

Hamilton, S. K., Sippel S. J., Calheiros, D. F. \& Melack, J. M. (1996) Chemical characteristics of surface waters of the southern Pantanal. In II Simpósio sobre Recursos Naturais e Socioeconômicos do Pantanal. Corumbá, MS. 89 - 100.

Hamilton, S. K., Sippel, S. J. \& Melack, J. M. (1996) Oxygen depletion and carbon dioxide and methane production in waters of the Pantanal wetland of Brazil. Biogeochemistry 30: 115-141.

Junk, W. J. \& Piedade, M. T. F. (1997) Plant life in the flood plain with special reference to herbaceous plants, In: The central Amazon floodplain, Ecology of a pulsing system, Editor, W.J. Junk, Springer, 147-181, 525p. 
Nogueira, F. M. B. (1989) Importância da macrófitas aquáticas Eichhornia azurea Kunth e Scirpus cubencis Poepp \& Kunth na ciclagem de nutrientes e nas principais variáveis limnológicas da Lagoa do Infernão. 147f. Dissertação. UFSCar, São Carlos.

Nunes da Cunha, C. \& Junk W. J. (1996) Composição florística de capões e cordilheiras: localização das espécies lenhosas quanto ao gradiente de inundação no Pantanal de Poconé, MT - Brasil, In: II Simpósio sobre Recursos Naturais e Socioeconômicos do Pantanal. Corumbá, MS. 387-205.

Nunes, J. R. S. \& Da Silva, C.J. (2005) variáveis limnológicas sob estandes de Eichhornia crassipes (Mart) Solms, no Sistema de baías Chacororé-Sinha Mariana, Pantanal de Mato Grosso. Uniciências.

Nunes, J. R. S. \& Da Silva C. J. (2009) Concentração de íons no sistema de baías Chacororé-Sinhá Mariana, Pantanal de Mato Grosso Uniciências.

Nunes, J. R. S.; Da Silva, C. J. \& Abdo, M.; (2012) As águas do Sistema de Baías Chacororé-Sinhá Mariana. IN: Água, Biodiversidade e Cultura do Pantanal, Estudos ecológicos e etnoecológicos no sistema de baías Chacororé-Sinhá Mariana, Org. Da Silva, C. J. \& Simoni, J. 272p.

Nunes, J. R. S.; Da Silva, C. J. \& Albernaz-Silveira, R.; (2012) Avifauna do Rio Cuiabá e do Sistema de Baías Chacororé-Sinhá Mariana. IN: Água, Biodiversidade e Cultura do Pantanal, Estudos ecológicos e etnoecológicos no sistema de baías Chacororé-Sinhá Mariana, Org. Da Silva, C. J. \& Simoni, J. 272 .

Nunes, J. R. S., Da Silva, C. J. \& Ferraz, L. (2017) Mato Grosso e seus biomas: Biodiversidade, Desafios Sócio Ambientais, Unidades de Conservação Iniciativas de Políticas Públicas e Privadas para a Conservação, Revista Gestão Universitária Vol. 07.

Nunes, J. R. S., Da Silva, C. J., Ikeda-Castrillon, S. K., \& Sander, N. L. (2020). Mudança na composição de assembleia de aves aquáticas associadas com mudanças no nível de água em uma Zona de Transição Terrestre Aquática no Pantanal de Mato Grosso, Brasil. Research, Society and Development, 9(10), e4479108555. https://doi.org/10.33448/rsd-v9i10.8555

Nunes, J. R. S., Loverde S., Pinto-Silva V., Ferraz L., Amorim A., Costa C. P., Mondim L. A., Silveira J. S., Favalessa O., Gonçalez C. H., Troy W. P. \& Urquiza N. G. (2006) Variação diária das características limnologicas da baía dos coqueiros, Pantanal de Poconé - MT, UNICiências, 10, 31-46p.

Penha, J. M., Da Silva, C. J. \& Bianchini-Junior, I. (1998) Análise do crescimento da macrófita aquática Pontederia lanceolata em área alagável do Pantanal Mato-grossense, Brasil, Revista brasileira de biologia, 58(2): 287-300.

Pinto-Silva, V. (1980) Variações Diurnas de Fatores Ecológicos em Quatro Lagoas Naturais do "Pantanal Mato-grossense” e seu estudo comparativo com dois lagos da Amazônia Central e um lago Artificial (Represa do Lobo, “Broa”, São Carlos, SP. (dissertação). UFScar - Universidade Federal de São Carlos, departamento de Ciências Biológicas. 281f).

Poi De Neiff, A. S. G., Neiff, J. J., Orfeo, O. \& Carignan, R. (1994) Quantitative importance of particulate matter retention by the roots of Eichhornia crassipes in the Paraná floodplain. Aquatic Botany, Amsterdam, 47(3-4), 213-223.

Pott, V. J. \& Pott, A. (2000) Plantas Aquáticas do Pantanal. EMBRAPA. Centro de Pesquisa Agropecuária do Pantanal (Corumbá, MS). - Brasília: Embrapa Comunicação para Transferência de Tecnologia, $404 \mathrm{p}$.

Pozer, C. G. \& Nogueira, F. (2004) Flooded native pastures of the northern region of the Pantanal of Mato Grosso: Biomass and primary productivity variations, Brazilian Journal of Biology, 64 (4): 859-866.

Ramachandra, T. V., Ahalya, N., Bhagat, A. K., Desai, S. R., Diwakar, K. M., Hrishikash, M., Lakshminarayana, H.; Mahesh, B., Payne, M., Ajay, N., Kneisel, N., Julka, P., Mohanta, P. K., Jha, R. K., Rajink, A. R., Rao, G. R., Samer, A., Sanjeeva, N. K., Sanjeeva, N., Sath iskumar, R., Somnath, H., Sreekantha, U., Sudhira, H. S. \& Mukri, V. (2002) Limnology, Energy and wetland research groups (www. limgis.com.br).

Rebouças, A. C., Braga, B., \& Tundisi, J. G. (2002) Águas doces no Brasil, capital ecológico, uso e conservação, (2a ed.), Escrituras. 703p.

Sabatini, R. A. (1985) Dinámica y productividad de Paspalum repens Bergies (canutillo) en un ambiente lenítico del valle aluvial del rio Paraná. Revue Hydrobiologie Tropicale, 18(1): 3-11.

Saijo, Y., Mitamura, O., Hino, K., Ikusima, I., Tundisi, J. G., Matsumura-Tundisi, T., Sunaga, T., Nakamoto, N., Fukuhara, H., Barbosa, F. A. R., Henry, R. \& Pinto-Silva, V. (1997) Physicochemical features of the rivers and lakes in Pantanal wetland, Jpn. J. Limnol., 58:69-82.

Santos, S. B. S. dos, Oliveira, Y. R., Silva, P. H. da, \& Abreu, M. C. de. (2017). Percepções dos moradores acerca de Typha angustifolia subsp. Domingensis (Pers.) Rohrb. (Typhaceae Juss.) em áreas alagadiças de Picos-PI, Nordeste do Brasil. Research, Society and Development, 4(3), 184-198. https://doi.org/10.17648/rsd-v4i3.68

Schessi, M. (1999) Floristic composition and structure of floodplain vegetation in the northern Pantanal of Mato Grosso, Brazil, Phyton, 39 (2), $303-336$.

Silva, R. L. (2002) Dinâmica espacial e produção primária do estande de Eichhornia azurea na baía dos Coqueiros (Pantanal de Mato Grosso, Brasil), Dissertação de mestrado. Universidade Federal de Mato Grosso, Instituto de Biociências, Cuiabá, Brazil.

Singh, S. B. \& Sahai, I.R. (1979) Seasonal changes in the biomass of Eichhornia crassipes (Mart.) Solms in Jalwania pon of Gorakhpur, Indian Journal Ecology 6: 30-34.

Soriano, B. M. A. (1996) Caracterização climática da sub-região da Nhecolândia, Pantanal-MS, In: II Simpósio sobre Recursos Naturais e Socioeconômicos do Pantanal. Manejo e Conservação, Corumbá, MS. 151-158.

Villar, C. A., Cabo, L., Vaithiayanathan, P. \& Bonetto, C. (2001) Litter decomposition of emergent macrophytes in a floodplain of the lower water Paraná river, Aquatic botany, 70, 105-116. 